Artikel

\title{
Design of Decision Support System for New Employee Acceptance with SAW and WP Method in CV Karya Lestari Abadi
}

Felivia Regie Tanjayal, Andi Leo ${ }^{2}$,

${ }^{1,2}$ Buddhi Dharma University, Information System, Banten, Indonesia

\begin{tabular}{l} 
SUBMISSION TRACK \\
\hline Received 1 January 2019; \\
Revised 12 January 2019; \\
Accepted 10 February 2019; \\
Available online 20 February 2019 \\
KEYWORD \\
\hline \begin{tabular}{l} 
Decision Support System Design, Employee \\
Acceptance, Simple Additive Weighting (SAW) \\
Method, Weight Product (WP). \\
KoRESPONDENSI \\
\hline E-mail: \\
feliviaregie@gmail.com
\end{tabular} \\
\hline
\end{tabular}

\begin{abstract}
A B $\quad \mathbf{S}$ T $\mathbf{R}$ A $\mathbf{C}$ T
The selection process for new employees at CV. Karya Lestari Abadi is carried out manually, the application file for new candidates will be evaluated by comparing the contents of the file with specified criteria. File selection that meets the criteria is then followed by an interview process. The series of processes is followed by a series of written tests, including psychological tests, academic potential tests and so on. This study aims to build a New Employee Recruitment Decision Support System using the Simple Additive Weighting (SAW) and Weight Product (WP) methods. These two methods were chosen because they can determine the weight value for each attribute, then proceed with the ranking process that will choose the best alternative from several alternatives. While the system implementation uses the PHP and MySQL programming languages as a database. With the decision support system can help the Recruitment in making decisions in the recruitment process in CV. Karya Lestari Abadi easier and faster.
\end{abstract}

\section{INTRODUCTION}

According to (Alex Rikki, 2016, p. 38) A large company is driven by people who are trained and have certain expertise and experience. Human Resources in a company in achieving its goals. Thus we need a decision support system for employee recruitment. Decision support system uses SAW and WP methods.

Decision support system variables are the criteria (attributes) that are assessed in fulfilling decisions, namely, the level of education, field tests and age of prospective employees. 


\section{FRAMEWORK}

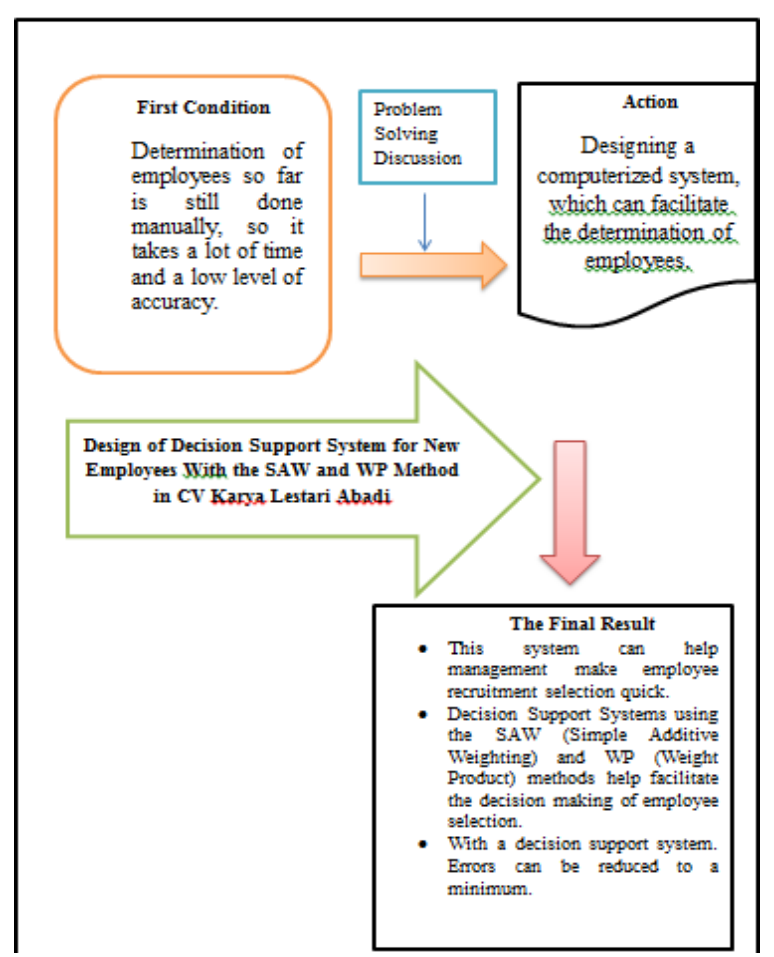

\section{METHODS}

Decision Support System (DSS) is a computer-based system or subsystem that aims to help decision makers (decision makers) by using technology, data, documents, science, or models to identify and solve problems, complete decision process, and making decisions (D. Schuff, D. Paradice, F. Burstein, DJ Power, and R. Sharda, 2011).

a. The SAW method or Simple Additive Weighting is a method often known as the weighted sum method. The purpose of the weighted sum is to find the weighted sum of the ratings in each alternative for all attributes or criteria.

$= \begin{cases}\frac{x_{i j}}{\max _{i} x_{i j}} & \text { Jika } j \text { adalah adalah atribut keuntungan (benefit) } \\ \frac{\min _{i} x_{i j}}{x_{i j}} & \text { jika j adalah atribut biaya (cost) }\end{cases}$

\section{Explanation:}

\footnotetext{
$\mathrm{r}_{\mathrm{ij}}=$ Normalized rating value

$\mathrm{x}_{\mathrm{i}} \quad=$ The attribute value owned by each criterion

$\operatorname{Max}_{i}=$ The biggest value of each criterion
}

Mini $_{\mathrm{i}}=$ The smallest value of each criterion
Bene $=$ The largest number of values is the best
Cost $=$ The smallest amount is best

Preference value for each alternative (Vi) explained as follows :

$$
V i=\sum_{j=1}^{n} w_{j} r_{i j}
$$

A greater $\mathrm{Vi}$ value indicates that the $\mathrm{Ai}$ alternative is preferred.

Explained:

a) $\mathrm{Vi}=$ Ranking for each alternative.

b) $\mathrm{Wj}=$ Ranking weight value (from each criterion).

c) $\mathrm{rij}=$ Normalized performance rating value.

b. Weighted Product Method (Basyaib, $2006,139)$ is a method of decision making by multiplying to connect attribute ratings, where the rating of each attribute must be raised first with the weight of the attribute in question.

$$
S_{i}=\prod_{j=1}^{n} x_{i j}{ }^{w_{j}} \text { with } i=1,2, \ldots, m
$$

Where $\mathrm{Wj}$ is a positive value for the profit attribute, and a negative value for the cost attribute.

Explanation:

$\Pi \quad$ : $\quad$ Product / Number of times

$\mathrm{S}_{\mathrm{i}} \quad$ : score of each alternative

$\mathrm{X}_{\mathrm{ij}}$ : alternative value "i" to the attribute "j"

$\mathrm{W}_{\mathrm{j}}$ : the weight of each attribute or criterion

$\mathrm{N}$ : many criteria 


\section{RESULT}

Table 1. Criteria Table

\begin{tabular}{lccc}
\hline Code & Criteria & Range & Score \\
\hline A1 & Experience & 5 & 0,3 \\
\hline A2 & Skills & 4 & 0,2 \\
\hline A3 & Education & 3 & 0,18 \\
\hline A4 & Interview & 3 & 0,18 \\
\hline A5 & Social status & 2 & 0,12 \\
\hline
\end{tabular}

Table 2. Experience Criteria Table

\begin{tabular}{ccc}
\hline No. & Experience & Range \\
\hline 1. & Tidak Ada & 1 \\
\hline 2. & 1 year Experience & 2 \\
\hline 3. & 2 year Experience & 3 \\
\hline 4. & 3 year Experience & 4 \\
\hline 5. & 4 year Experience & 5
\end{tabular}

Table 3. The Skills Criteria Table

\begin{tabular}{lcc}
\hline No. & Skills & Range \\
\hline 1. & $0-1$ Skill & 1 \\
\hline 2. & 1-2 Skill & 2 \\
\hline 3. & $2-3$ Skill & 3 \\
\hline 4. & 3-4 Skill & 4 \\
\hline 5. & 4-5 Skill & 5 \\
\hline
\end{tabular}

Table 4. Table of Education Criteria

\begin{tabular}{llc}
\hline \multicolumn{1}{c}{ No. } & Pendidikan & Bobot \\
\hline 1. & Elementary school & 1 \\
\hline 2. & Middle School & 2 \\
\hline 3. & High school & 3 \\
\hline 4. & Vocational School & 4
\end{tabular}

Table 5. Interview Criteria

\begin{tabular}{c|c|c}
\hline \multicolumn{1}{c|}{ No. } & Interview & Score \\
\hline 1. & $0-50$ & 1 \\
\hline
\end{tabular}

\begin{tabular}{l|l|l}
\hline 2. & $50-70$ & 2 \\
\hline 3. & $70-80$ & 3 \\
\hline 4. & $80-90$ & 4 \\
\hline 5. & $90-100$ & 5 \\
\hline
\end{tabular}

Table 6. Social Status Criteria

\begin{tabular}{llc}
\hline No. & $\begin{array}{r}\text { Status } \\
\text { Sosial }\end{array}$ & Bobot \\
\hline 1. & Married & 3 \\
\hline 2. & Single & 2 \\
\hline
\end{tabular}

Table 7. Normalized Table of Simple Additive Weighting

\begin{tabular}{|c|c|c|c|c|c|}
\hline Alternative & Experience & Skills & Education & Interview & $\begin{array}{c}\text { Social } \\
\text { Status }\end{array}$ \\
\hline A1 & 0.4 & 0.2 & 1 & 0.2 & 0.8 \\
\hline A2 & 0.6 & 0.8 & 1 & 0.6 & 1 \\
\hline A3 & 0.8 & 0.4 & 0.6 & 0.8 & 0.6 \\
\hline A4 & 0.8 & 1 & 0.8 & 1 & 1 \\
\hline A5 & 1 & 1 & 1 & 0.4 & 1 \\
\hline
\end{tabular}

The following are the results of calculations and ranking :

Table 8. Ranking of Simple Additive Weighting Results

\begin{tabular}{|l|l|r|}
\hline Code & Pref Score & Ranks \\
\hline A1 & 0.212855638 & 3 \\
\hline A2 & 0.237091675 & 2 \\
\hline A3 & 0.141201264 & 5 \\
\hline A4 & 0.160168599 & 4 \\
\hline A5 & 0.248682824 & 1 \\
\hline
\end{tabular}

The following are the results of the calculation of the Weighted Product Method of Total and Ranks: 
Table 9. Normalization of Weighted Products

\begin{tabular}{|l|l|c|}
\hline Total S & Total V & Ranks \\
\hline 1.501310729 & 0.106782295 & 5 \\
\hline 2.845254887 & 0.202371728 & 3 \\
\hline 2.743789593 & 0.195154903 & 4 \\
\hline 3.725062185 & 0.264948942 & 1 \\
\hline 3.244129918 & 0.230742132 & 2 \\
\hline
\end{tabular}

\section{DISCUSSION}

Simple Additive Weighting method has advantages compared to other decision support system methods, vizits ability to make judgments more precisely because it is based on the value of criteria and the level of importance needed. In the SAW method, the selection of the best alternative is done from a number of alternatives, then a ranking process is carried out in which the sum of the weighted values of all criteria is added after determining the value weights of each criterion (Aditiya Hermawan, 2019).

\section{CONCLUSION}

Based on the results of the writing and analysis of the Decision Support System
Design for Acceptance of new employees that have been submitted in the previous chapters, the following conclusions can be drawn:

1. Employee acceptance system at $\mathrm{CV}$ Karya Lestari Abadi becomes quick.

2. Employees data can be stored better and systemized.

3. The decision making process becomes more accurate with the use of the Decision Support System of the SAW and WP methods.

\section{SUGGESTION}

Based on the results of the study, here are some of the shortcomings in this new Employee Acceptance decision making system, then there are some suggestions that are expected to help improve this system so it is even better, including:

1. This employee recruitment system is still not online, so it is expected that in the future it will become an online system.

2. Psychology tests need to be added to the system.

3. It is hoped that in the future more useful features can be added.

\section{REFERENCES}

[1] Alex Rikki, M. M. (2016). EMPLOYEE ACCEPTANCE SUPPORT SYSTEM. JIPN (Journal of Informatics Pelita Nusantara), 38.

[2] Anhar. (2010). Self-taught Mastering PHP and MYSQL. Jakarta: Mediakata.

[3] Arief, M. R. (2011). Dynamic Web Programming using Php and Mysql. Yogyakarta: Andi.

[4] Black, R. (2009). Managing the Testing Process :mPratical Tools and Techniques for managing Hardware and Software Testing, 3rd Edition. Inc. In R. Black, Managing the Testing Process :mPratical Tools and Techniques for managing Hardware and Software Testing, 3rd Edition.Indiana:Wiley Publishing, Inc. (p. 3). Indiana: Wiley Publishing.

[5] D. Schuff, D. Paradice, F. Burstein, D. J. Power, and R. Sharda. (2011). Decision Support: An Examination of the DSS Discipline. New York: Springer.

[6] Darmawan, D. (2013). Quantitative Research Methods. Bandung: PT Remaja Rosdakarya. 
[7] Firmansyah. (2018). https://www.nesabamedia.com. Retrieved 06 27, 2018, from Nesaba Media copyright 2018: https://www.nesabamedia.com/pengertian-xampp/

[8] Hermawan, A. (2019). The Hotel Recommendation System Using SAW (Simple Additive Weighting) And TOPSIS (The Technique for Order of Preference by Similarity to Ideal Solution) Method. bit-Tech, 1(3), 131-145.

[9] Kristanto, A. (2008). Design of Information Systems and Applications. Yogyakarta: Gava Media.

[10] A. Pataropura, R. Riki, and J. Manu, "Decision Support System for Selection of Assembly Using Profile Matching Method and Simple Additive Weighting Method (Case Study: GKIN Diaspora Church)", bt, vol. 2, no. 1, pp. 43-52, Oct. 2019.

\section{BIOGRAPHY}

Felivia Regie Tanjaya (First Author) Graduated from the Information Systems Study Program (S1) in the Enterprise System, 2019..

Andi Leo S.Kom., M.Kom (Second Author) is a Lecturer from the Buddhi Dharma University Faculty of Science and Technology, Tangerang. He obtained his Bachelor of Computer (S.Kom) degree from Bina Nusantara University in 1989. And continued his Master of Computer (M.Kom) Postgraduate program at Bunda Mulia University. 